\title{
Attraction of Adult Chironomidae (Diptera) to Incandescent Light Under Laboratory Conditions
}

\author{
ARSHAD ALI, STEPHEN R. STAFFORD, \\ RICHARD C. FOWLER, AND BRUCE H. STANLEY'
}

University of Florida, IFAS, Central Florida Research and Education Center, P.O. Box 909, Sanford, Florida 32771

\begin{abstract}
Environ. Entomol. 13: 1004-1009 (1984)
ABSTRACT The attraction of three chironomid species, Glyptotendipes paripes Edwards, Chironomus crassicaudatus Malloch, and Polypedilum halterale (Coquillett), to incandescent light of different colors and wattages was studied. Field-captured adults were released from the center of a dark room ( 9 by $9 \mathrm{~m}$ ) equipped with a New Jersey light trap in each corner. The effects of color were determined by using 100-W lamps of red, orange, yellow, green, blue, and white. The effects of light intensity were studied by using 100,60,40, and 25-W white lamps. Measurements of light intensity of each lamp were taken. Among the colors tested in two separate combinations, white light attracted the maximum numbers of adults and red light the least. The three species exhibited a similar behavior. Among white light of different intensities, the maximum attraction of $G$. paripes occurred toward the highest intensity and the minimum toward the lowest intensity. The midge species responded more to the quantity (power or intensity) than to the quality (color or wavelength) of light.
\end{abstract}

AQUATIC CHIRONOMID midges emerging in large numbers often create a serious nuisance, as well as economic and medical problems, for people living or working near midge-breeding sources. Many species of midges emerge in the dark with peak emergence usually occurring within 2 to $3 \mathrm{~h}$ after sunset (Ali 1980a, Ali and Mulla 1979). The adults are attracted to lights around which they swarm at night. The swarming activity gradually subsides after midnight. In the daytime, the adults rest on walls, vegetation, and other objects in close proximity to their breeding sites, flying only when disturbed. However, adults of a few generally smallsized species have been observed to swarm around objects or in the open during the daytime. The problems caused by adult midges have been previously outlined (Ali 1980b, Cranston et al. 1981).

In the past decade, the city of Sanford in Seminole County, central Florida, has suffered increased annoyance and economic loss due to chironomid swarms emanating primarily from Lake Monroe and a man-made water cooling reservoir adjacent to the city. An economic study revealed that Sanford suffers an annual loss of 3 to 4 million dollars due to chironomid related problems and that at least 10 counties in Florida have midge problems. $^{2}$

The chemical control of midges in small habitats (up to $200 \mathrm{ha}$ ) with larvicides and insect growth

\footnotetext{
' Present address: New York State Agric. Exp. Stn., Dept. of Entomology, Cornell University, Geneva, NY 14456.

' Economic Impact Statement, 1977, Blind Mosquito (Midge) Task Force, Greater Sanford Chamber of Commerce, Seminole County, Fla.
}

regulators practiced in some parts of the United States (Ali and Mulla 1977a,b, Polls et al. 1975) is not feasible or economical in the large midge habitats of Florida, each covering thousands of hectares. Also, many of these habitats are either part of, or feed into, river systems. Chemicals used in such systems are subject to displacement and dilution and would be unacceptable from an environmental standpoint. In such situations, biological control strategies and cultural control techniques based on the behavior of adults of the pest species are needed. This paper reports the adult attraction behavior of three midge species to incandescent lights of different colors and wattages under laboratory conditions.

\section{Materials and Methods}

Tests were conducted during the summer of 1982 and 1983 in an empty room ( 9 by $9 \mathrm{~m}$ ) with a ceiling $3.5 \mathrm{~m}$ high. The doors and windows in the room were covered to block out extraneous light. Four New Jersey light traps equipped with suction mechanism (Mulhern 1942) were used to test four different combinations of light color and wattage. One trap was hung in each corner of the room from beams under the ceiling. The trap was ca. $30 \mathrm{~cm}$ away from each side wall with the bottom of the trap $2.5 \mathrm{~m}$ above the floor. In these studies, commonly available incandescent light bulbs (lamps), also known as general purpose A-line lamps (General Electric Co., Cleveland, Ohio) were used. In the first test, 100-W lamps of yellow (YL), blue (BL), green (GL), and red (RL) were used. The second test consisted of 100-W 
lamps of white (WL), YL, orange (OL), and RL. The third test contained only WL 100-W lamps. In the fourth test WL lamps of $100,60,40$, and $25 \mathrm{~W}$ were used. The WL lamps used in these studies were frosted (inside) while the inner lining of all colored lamps was enameled. The yellow lamp was also named the Bug-Lite by its manufacturer and was not supposed to attract night flying insects as indicated on its container.

The qualitative characteristics (wavelengths) of the lamps used are previously available (General Electric Co. 1978). All of the color lamps emitted broad bands of wavelengths in the visible spectrum. The wavelengths emitted by $\mathrm{BL}$ are between 430 and $490 \mathrm{~nm}$, GL between 490 and 550 $\mathrm{nm}, \mathrm{YL}$ between 550 and $590 \mathrm{~nm}$, OL between 590 and $620 \mathrm{~nm}$, and RL between 620 and 770 $\mathrm{nm}$ (Hollingsworth 1961). The radiant energy emitted by WL was in all visible wavelengths of 390 to $770 \mathrm{~nm}$.

For these studies, adult midges were captured in the field by using a sweep net. The collections were gently transferred to screened transparent plastic cages identical to the midge-rearing units described by Biever (1965). The collections were made in the late afternoon on each occasion; several thousand adult midges were captured. At least five cages were used at a time to contain the adults. The caged adults were taken to the laboratory and were placed for acclimatization for 3 to $4 \mathrm{~h}$ on top of a $0.75-\mathrm{m}$ high square table located in the center of the experimental room, ca. $6 \mathrm{~m}$ distance from each trap, and the traps were activated. Other lights in the room and the air cooling or heating units were inactivated during the periods of experimentation. The adults were released from the cages in the evening ( 8 to 9 p.m.). They immediately flew toward the traps upon release. Trapping was conducted for 8 to $10 \mathrm{~h}$. The following morning the collection jars containing the adults were removed and capped. Immediately before releasing the adults on each occasion, the light intensity of each lamp was measured with a LI-COR light meter (Li-Cor, Inc., Lincoln, Nebr.) equipped with a photometric sensor (LI-210SB). The intensity was measured at six locations marked at $1-\mathrm{m}$ intervals along each of the four permanently marked lines radiating from the center to each corner of the room. All four traps in a test combination were illuminated and the intensity was measured by placing the sensor $2.5 \mathrm{~m}$ above the floor and directly facing the light source. Light was measured at the same locations and height in each test, and the mean lux along the path between the release station and each trap was calculated. Each set of colors or wattages was tested at least four times by relocating the lamps so that each lamp occupied each corner of the room at least once.

The adults trapped were identified and counted in the laboratory. The significance of lamp, color, wattage, and intensity in attracting adults of different midge species was elucidated by contingen- cy table analysis using log-linear models with quantitative factors (Whittaker and Aitkin 1978); a hierarchy of increasingly more complex structural models was fitted as in stepwise regression. In these models, the expected count for each cell in the table was modeled as a linear function of the systematic effects of the qualitative factors: species (S), lamp (L), color (C), wattage (W), and their interactions when measured on a logarithmic scale. The quantitative measure (mean lux) of light intensity (I) was fitted as an exponential (linear on a logarithmic scale) covariate along with its interactions with other factors. In tests 1 and 2 , the hierarchy was designed to elucidate the specificity of midge response to the lamps. Intensity was fitted first because it was an attribute common to all of the lamps. Next, terms specifying the influence of lamp color in addition to its intensity (i.e., C + $\mathrm{C} \times \mathrm{I})$ were added to the model. Finally, terms defining differences among the species in their response to intensity and color (i.e., $\mathrm{S} \times \mathrm{I}+$ $\mathrm{S} \times \mathrm{C}+\mathrm{S} \times \mathrm{C} \times \mathrm{I}$ ) were added. The hierarchy was designed to ascertain lamp homogeneity in test 3 and the importance of intensity in test 4 . The various model parameters were estimated by maximum likelihood, assuming multinomial sampling with fixed replicate and species catch totals. After fitting the models, the deviance (Nelder and Wedderburn 1972), a measure of goodness-of-fit, attributable to each group of factors added, was partitioned for each test. Model fitting was conducted using the GENSTAT program (Alvey et al. 1977).

\section{Results and Discussion}

Glyptotendipes paripes Edwards, Chironomus crassicaudatus Malloch, and Polypedilum halterale (Coquillett) were used in tests in sufficient numbers for statistical analysis. Several other species, Chironomus decorus Johannsen, Goeldichironomus carus (Townes), Goeldichironomus holoprasinus (Goeldi), Cryptochironomus fulvus Johannsen, Parachironomus sp., Tanytarsus spp., Rheotanytarsus spp., Coelotanypus concinnus (Coquillett), Coelotanypus scapularis (Loew), Procladinus sublettei (Roback), and Cricotopus spp. were also present and attracted to lights but in insufficient numbers for analysis.

In test 1 , YL attracted $83.50 \%$, BL $12.41 \%$, GL $2.90 \%$, and RL $1.24 \%$ of the total G. paripes attracted to these lights (Fig. 1). The lamp wattage for each of these colors was $100 \mathrm{~W}$ and the measurements of light intensity for YL, BL, GL, and RL were $22.79,1.98,1.83$, and 2.70 lux, respectively. In test $2, G$. paripes responded the most $(82.80 \%)$ to WL and the least $(0.48 \%)$ to RL. The YL attracted $14.79 \%$ and OL $1.93 \%$ of the total $G$. paripes occurring in this test. All lamps in the test were $100 \mathrm{~W}$ but due to the different colors the intensity differed and ranged from 30.89 lux for WL to 2.97 lux for RL. In test 3, G. paripes was 
Test 1

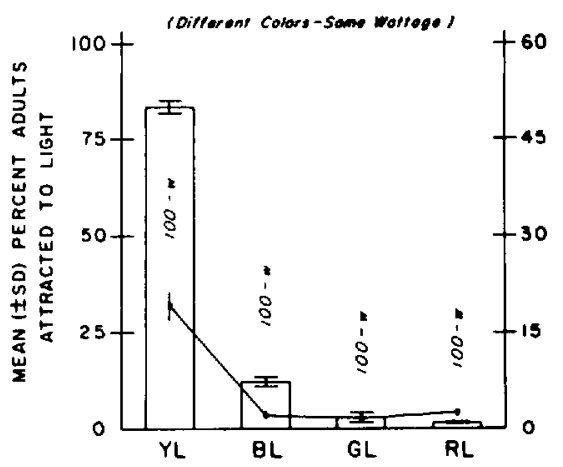

Test 2

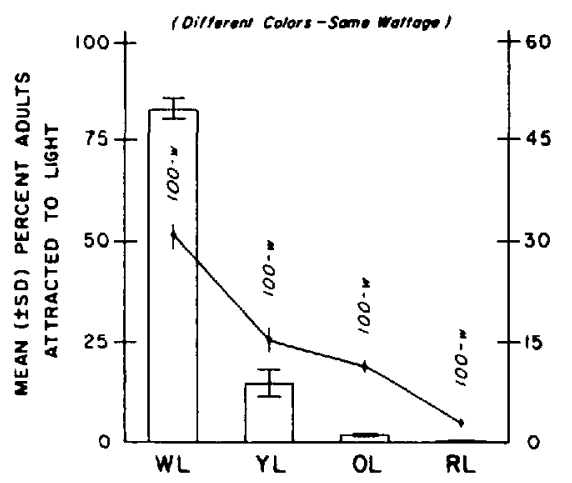

Test 3

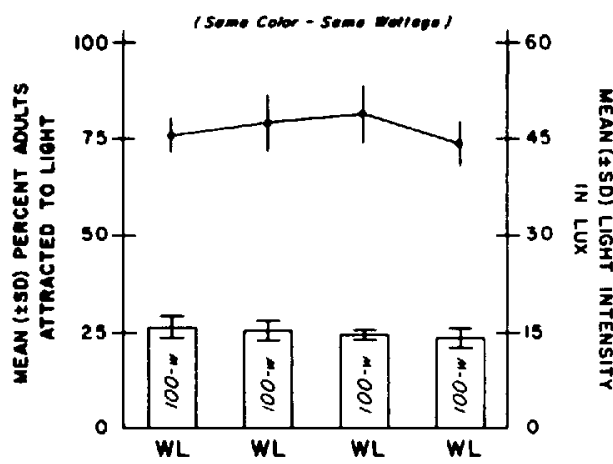

Test 4

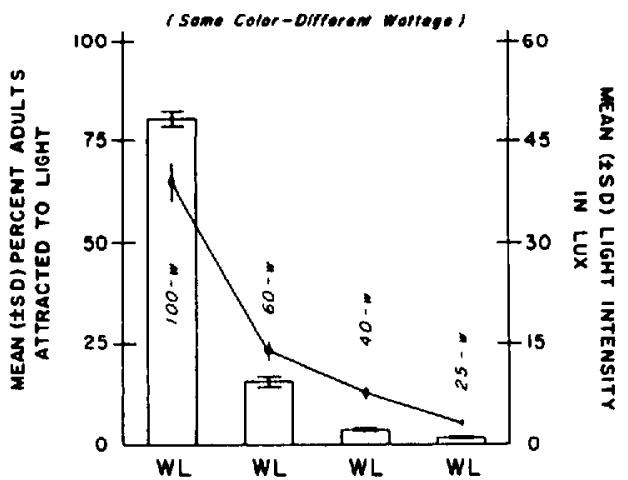

Fig. 1. Attraction of adult G. paripes to four different color or wattage combinations of light tested in the laboratory; the bars represent the percentage of adults attracted to light while the line graphs indicate the light intensity.

attracted in almost equal numbers to the same light color (WL) of the same wattage (100 W) with intensities ranging from 47.52 to 41.64 lux. However, it is obvious from test 4 that light of the same color (WL) but of different wattages $(100,60,40$, and 25 ) attracted varying numbers of $G$. paripes. The WL of $100 \mathrm{~W}$ and an intensity of 38.84 lux attracted $84.30 \%$ of the total G. paripes, while WL of $25 \mathrm{~W}$ and an intensity of 3.14 lux attracted only $0.96 \%$. The $60-W$ WL (intensity 13.95 lux) attracted $15.48 \%$ and $40-\mathrm{W}$ WL (intensity $7.55 \mathrm{lux}$ ) attracted $3.21 \%$ of the total G. paripes trapped (Fig. 1).

The response of C. crassicaudatus to lights in test 1 and 2 (Fig. 2) was generally similar to that of $G$. paripes. In test $1, \mathrm{YL}$ attracted $88.35 \%, \mathrm{BL}$ $5.55 \%$, GL. $5.23 \%$, and RL $0.87 \%$ of the total $C$. crassicaudatus attracted to these lights. Similarly, in test 2, C. crassicaudatus was attracted the most $(84.49 \%)$ to the brightest light (WL) and the least $(0.51 \%)$ to the dimmest light (RL) in the combination. The phototactic response of $P$. halterale in test 2 (Fig. 3) was also similar to G. paripes and C. crassicaudatus.

The analysis of deviance for each of the four tests (Table 1) indicates that almost all of the considered factors had some significant effect. Such sensitivity of the analysis to relatively small effects is to be expected when the sample size is large. It is also possible that heterogeneity among the replicates in midge response to lamp type due to biological interactions among the individuals may have exaggerated the importance of some of the sources of variation (e.g., residual deviance). However, from a practical standpoint, the percentage of contribution to the total deviance (\% TD) is the most meaningful statistic for comparing the relative importance of each factor or a group of factors. In test 1 , color had little influence on the catch once the effect of intensity was removed. Also, species-specific differences in response to color and intensity were negligible. In test 2 , light intensity was again the only important factor influencing the catch; color and species specific effects amounted to only $2.3 \%$ TD. In test 3 , light intensity had little effect and the only factor causing differences in the catches among the replicates was the sample size. This was to be expected because the intensity and other attributes of $100-\mathrm{W}$ WL lamps were essentially the same. Test 4 further 
Test 1

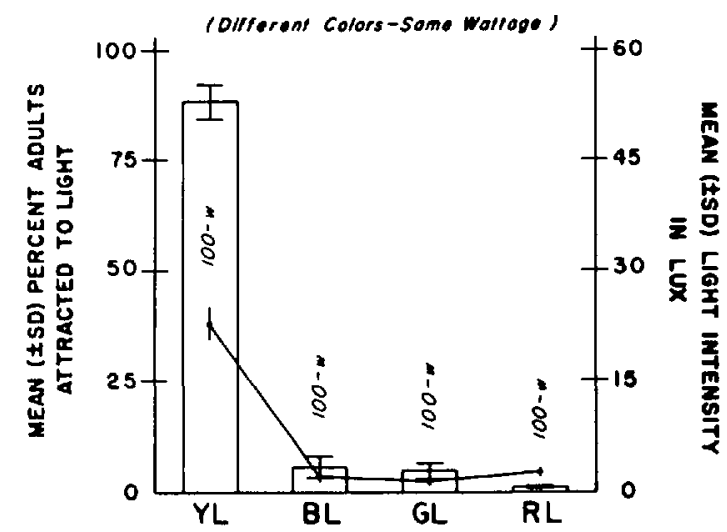

Test 2

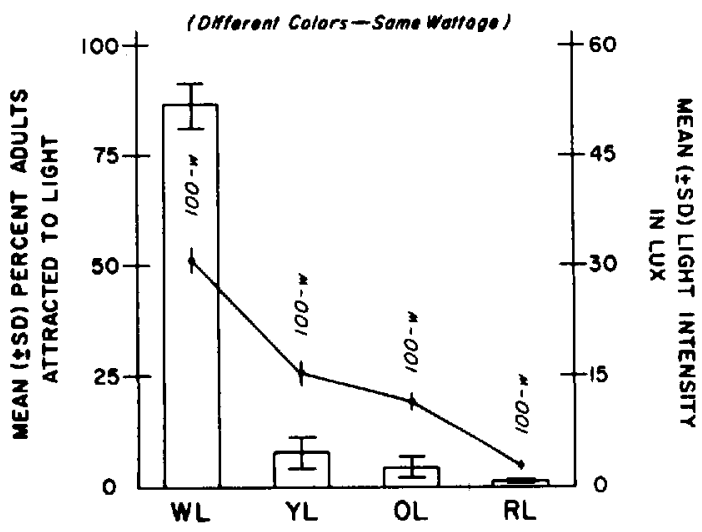

Fig. 2. Attraction of adult C. crassicaudatus to two different color combinations of light tested in the laboratory.

supports the observations made in tests 1 and 2 that light intensity is the predominant attribute of the lamps tested in attracting the adult midges (Table 1). After light intensity, heterogeneity in the total catch among the replicates and species was the most important factor in all tests (except test 3 ) in influencing the variation in catch among the four traps.

The attraction of adult insects to light has been studied by numerous scientists in the past three centuries. A vast majority of this work has been conducted on economically important terrestrial insects. Heinton (1974) has provided an excellent review of this subject. Studies on attraction of a variety of night-flying insects to light have shown that, in many cases, an insect species or a group of insects exhibited a specific response to a certain range of wavelengths in the electromagnetic spectrum. For example, the near ultraviolet region $(300-390 \mathrm{~nm})$ is the most attractive radiant energy

Test 2

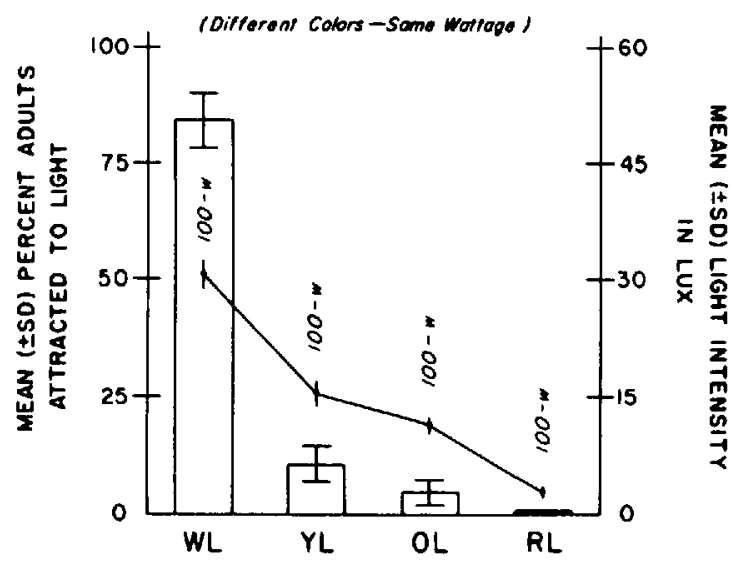

Fig. 3. Attraction of adult P. halterale to lights tested in the laboratory. to a large number of insects of economic importance, such as the cabbage looper (Trichoplusia ni [Hübner]), tobacco hornworm (Manduca sexta [Johannsen]), tomato hornworm (Manduca quinquemaculata [Haworth]), pink bollworm (Pectinophora gossypiella [Saunders]), codling moth (Laspeyresia pomonella [L.]), corn earworm ( $\mathrm{He}$ liothis zea [Boddie]), and others (Heinton 1974, Menear 1961, Glick and Hollingsworth 1954, Taylor and Deay 1950), while the adult boll weevil (Anthonomus grandis Boheman) was shown to have a maximum response to wavelengths in the blue-green region (470-515 $\mathrm{nm}$ ) of the visible spectrum (Hollingsworth et al. 1964). Among aquatic Diptera, Belton and Pucat (1967) reported that the biting midge (Culicoides sanguisuga [Coquillett]) showed strong attraction to ultraviolet light. In contrast, the adult mosquito Aedes aegypti (L.) showed a preference for the near infrared region (Magnum and Callahan 1968). Species of Simuliidae (Williams and Davis 1951) and many other Diptera were also reported to be attracted to light (Frost 1957).

The present study shows that three species of midges were attracted to the various colors but they responded the most to WL and further among WL of different intensities. The maximum attraction of G. paripes occurred toward the source of highest intensity in the test combination. Thus, it is obvious that these species responded more to the quantity (power or intensity) than to the quality (color or wavelength) of light, although some preference for wavelengths in the yellow-orange region (550-620 nm) may exist.

The attraction of adult chironomid midges to light has been previously reported (Frost 1957, Belton and Pucat 1967) but there are no qualitative or quantitative data on chironomids in the literature with which to compare the results of the present study. However, the response of some mosquito species, A. nigromaculis (Ludlow), Culex 
Table 1. Analysis of deviance for four tests concerning attraction of adult midges, G. paripes, C. crassicaudatus, and $P$. halterale to incandescent lamps of different colors or wattages

\begin{tabular}{|c|c|c|c|c|}
\hline $\begin{array}{l}\text { Lamp color } \\
\text { or wattage } \\
\text { combination }\end{array}$ & Source of variation & $\mathrm{df}$ & $\begin{array}{l}\text { Change in } \\
\text { deviance }^{a}\end{array}$ & $\begin{array}{l}\% \text { Of total } \\
\text { deviance } b\end{array}$ \\
\hline \multicolumn{5}{|c|}{ Test $1(24,190$ adults caught $)$} \\
\hline $\begin{array}{l}\text { YL, BL, GL, RL } \\
\text { (all } 100 \mathrm{~W})\end{array}$ & $\begin{array}{l}\mathrm{I} \\
\mathrm{C}+\mathrm{C} \times \mathrm{I} \\
\mathrm{S} \times \mathrm{I}+\mathrm{S} \times \mathrm{C}+\mathrm{S} \times \mathrm{C} \times \mathrm{I} \\
\text { Residual }\end{array}$ & $\begin{array}{r}1 \\
6 \\
7 \\
10\end{array}$ & $\begin{array}{r}39,968^{* *} \\
2,037^{* *} \\
497^{* *} \\
102^{* *}\end{array}$ & $\begin{array}{r}88.3 \\
4.5 \\
1.1 \\
0.2\end{array}$ \\
\hline \multicolumn{5}{|c|}{ Test 2 (21,482 adults caught) } \\
\hline $\begin{array}{l}\text { WL, YL, OL, RL } \\
\text { (all } 100 \mathrm{~W} \text { ) }\end{array}$ & $\begin{array}{l}\mathrm{I} \\
\mathrm{C}+\mathrm{C} \times \mathrm{I} \\
\mathrm{S} \times \mathrm{I}+\mathrm{S} \times \mathrm{C}+\mathrm{S} \times \mathrm{C} \times \mathrm{I} \\
\text { Residual }\end{array}$ & $\begin{array}{r}1 \\
6 \\
14 \\
15\end{array}$ & $\begin{array}{r}36,149^{* *} \\
499^{* *} \\
456^{* *} \\
166^{* *}\end{array}$ & $\begin{array}{r}87.7 \\
1.2 \\
1.1 \\
0.4\end{array}$ \\
\hline \multicolumn{5}{|c|}{ Test $3(7,729$ adults caught $)$} \\
\hline $\begin{array}{l}\text { Four WL } \\
\quad \text { (all } 100 \mathrm{~W} \text { ) }\end{array}$ & $\begin{array}{l}\mathrm{L} \\
\mathrm{I} \\
\mathrm{L} \times \mathrm{I} \\
\text { Residual }\end{array}$ & $\begin{array}{l}3 \\
1 \\
3 \\
5\end{array}$ & $\begin{array}{l}27^{* * *} \\
30^{* *} \\
8^{*} \\
13^{*}\end{array}$ & $\begin{array}{l}2.5 \\
2.8 \\
0.8 \\
1.3\end{array}$ \\
\hline \multicolumn{5}{|c|}{ Test $4(6,880$ adults caught $)$} \\
\hline $\begin{array}{l}\text { Four WL } \\
\qquad(25,40,60,100 W)\end{array}$ & $\begin{array}{l}\text { I } \\
W \\
W \times I \\
\text { Residual }\end{array}$ & $\begin{array}{l}1 \\
3 \\
3 \\
5\end{array}$ & $\begin{array}{c}10,260^{* * *} \\
474^{* *} \\
4 \\
4\end{array}$ & $\begin{array}{l}90.4 \\
4.2 \\
0.05 \\
0.05\end{array}$ \\
\hline
\end{tabular}

${ }^{a}$ Deviance $=-2 \log _{e}(L)$, where $L$ is the likelihood function (multinomial) evaluated at its maximum. The change in deviance is an approximately asymptotic chi-square distributed with $\mathrm{df}$ under the null hypothesis, that the factor(s) does not affect the contingency table cell frequencies. $*$, Significant at the $5 \%$ level; ${ }^{* *}$, significant at the $1 \%$ level.

${ }^{b}$ Remaining deviance is attributable to heterogeneity among the replicate and species catch totals.

tarsalis (Coquillett), and C. peus Speiser, was previously shown to be directly proportional to light intensity (Barr and Boreham 1960).

The attraction of midge species to light is of practical significance in the development of an integrated control program of these pestiferous insects. Many large lakes in the central Florida area (and perhaps elsewhere) are surrounded by a high density of homes and businesses interspersed with relatively less-inhabited areas. It is suggested that dimmer lights be used in areas affected by midges and that brighter lights be installed and used in the less-inhabited areas at the time of midge nuisance. This practice would probably draw some of the adult populations away from the affected residential and business localities. Such lights could also be installed on the already existing wooden poles (channel markers) in a number of these lakes to discourage the adult migration to the lake peripheral urbanized areas. Suitable midge adulticides could be used in the localized areas where the adults are drawn.

\section{Acknowledgment}

This article is Fla. Agric. Exp. Stn. Journal Series No. 5260 .

\section{References Cited}

Ali, A. 1980a. Diel adult eclosion periodicity of nuisance chironomid midges of central Florida. Environ. Entomol. 9: 365-370. 1980b. Nuisance chironomids and their control: a review. Bull. Entomol. Soc. Am. 26: 3-16.

Ali, A., and M. S. Mulla. 1977a. Chemical control of nuisance midges in the Santa Ana River Basin, southern California. J. Econ. Entomol. 70: 191-195.

1977b. The IGR diflubenzuron and organophosphorus insecticides against nuisance midges in man-made residential-recreational lakes. J. Econ. Entomol. 70: 571-577.

1979. Diel periodicity of eclosion of adult chironomid midges in a residential-recreational lake. Mosq. News 39: $360-364$.

Alvey, N. G., C. F. Banfield, R. I. Baxter, J. C. Gower, W. J. Krzanowski, P. W. Lane, P. K. Leech, J. A. Nelder, R. W. Payne, K. M. Phelps, C. E. Rogers, G. J. S. Ross, H. R. Simpson, A. D. Todd, R. W. M. Wedderhurn, and G. N. Wilkinson. 1977. GENSTAT: a general statistical program. Ver. 4.03. Rothamsted Experiment Station, Harpenden, England.

Barr, A. R., and M. M. Boreham. 1960. Light intensity and the attraction of mosquitoes to light traps. J. Econ. Entomol. 53: 876-880.

Belton, P., and A. Pucat. 1967. A comparison of different lights in traps for Culicoides (Diptera: Ceratopogonidae). Can. Entomol. 99: 267-272.

Biever, K. D. 1965. A rearing technique for the colonization of chironomid midges. Ann. Entomol. Soc. Am. 58: 135-136.

Cranston, P. S., M. O. Gad-El-Rab, and A. B. Kay. 1981. Chironomid midges as a cause of allergy in the Sudan. Trans. R. Soc. Trop. Med. Hyg. 75: 1-4.

Frost, S. W. 1957. The Pennsylvania insect trap. J. Econ. Entomol. 50: 287-292.

General Electric Company. 1978. Light and color. Publ. TP-119. General Electric Co., Cleveland, Ohio. Glick, P. A., and J. P. Hollingsworth. 1954. Re- 
sponse of the pink bollworm moth to certain ultraviolet and visible radiation. J. Econ. Entomol. 47: 8186.

Heinton, T. E. 1974. Summary of investigations of electric insect traps. Agric. Res. Serv. Tech. Bull. 1498. U.S. Dept. of Agriculture, Washington, D.C.

Hollingsworth, J. P. 1961. Relation of wavelength to insect response. In Response of insects to induced light. U.S. Dep. Agric. Agric. Res. Serv. 20-10: 9-25.

Hollingsworth, J. P., R. L. Wright, and D. A. Lindquist. 1964. Spectral response characteristics of the boll weevil. J. Econ. Entomol. 57: 38-41.

Magnum, C. L., and P. S. Callahan. 1968. Attraction of near-infrared radiation to Aedes aegypti (Linnaeus). Ibid. 61: 36-37.

Menear, J. R. 1961. Response of tobacco and tomato hornworm moths to monochromatic radiation in the near ultra-violet. M.S. thesis, Virginia Polytechnic Institute \& State University, Blacksburg, $\mathrm{Va}$.

Mulhern, T. D. 1942. New Jersey mechanical trap for mosquito surveys. N.J. Agric. Exp. Stn. Circ. 421
Nelder, J. A., and R. W. N. Wedderburn. 1972. Generalized linear models. J. Roy. Stat. Soc. Ser. A 135 370-384.

Polls, I., B. Greenberg, and C. Lue-Hing. 1975. Control of nuisance midges in a channel receiving treated municipal sewage. Mosq. News 35: 533-537.

Taylor, J. G., and H. O. Deay. 1950. Electric lamps and traps in corn borer control. Agric. Eng. 31: 503532.

Whittaker, J., and M. Aitkin. 1978. A flexible strategy for fitting complex log-linear models. Biometrics 34: 487-495.

Williams, C. B., and L. Davis. 1951. Simuliidae attracted at night to a trap using ultraviolet light. Nature (London) 179: 924-925.

Received for publication 20 December 1983; accepted 10 April 1984. 